110 Nordic Council of Ministers

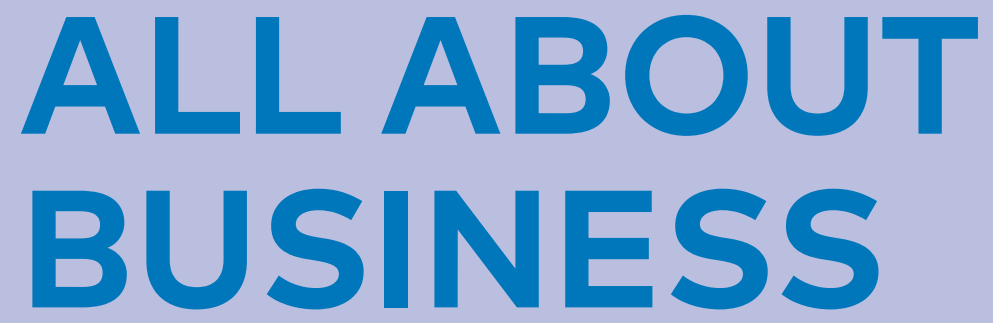

NORDIC WOMEN ON BOARDS AND IN LEADERSHIP

THINK-PIECE 


\section{ALL ABOUT BUSINESS}

Nordic women on boards and in leadership

Iselin Løvslett Danbolt

ISBN 978-92-893-4750-1 (PRINT)

ISBN 978-92-893-4751-8 (PDF)

http://dx.doi.org/10.6027/ANP2016-779

ANP 2016:779

(c) Nordic Council of Ministers 2016

Layout: Gitte Wejnold

Photo: norden.org, unsplash.com, Scanpix

Print: Rosendahls

Copies: 160

Printed in Denmark

This publication has been published with financial support by the Nordic Council of Ministers. However, the contents of this publication do not necessarily reflect the views, policies or recommendations of the Nordic Council of Ministers.

www.norden.org/nordpub

\section{Nordic co-operation}

Nordic co-operation is one of the world's most extensive forms of regional collaboration, involving Denmark,

Finland, Iceland, Norway, Sweden, and the Faroe Islands, Greenland, and Åland.

Nordic co-operation has firm traditions in politics, the economy, and culture. It plays an important role in European and international collaboration, and aims at creating a strong Nordic community in a strong Europe.

Nordic co-operation seeks to safeguard Nordic and regional interests and principles in the global community. Common Nordic values help the region solidify its position as one of the world's most innovative and competitive.

\section{Nordic Council of Ministers}

Ved Stranden 18

DK-1061 Copenhagen $\mathrm{K}$

$+4533960200$ 
110 Nordic Council of Ministers

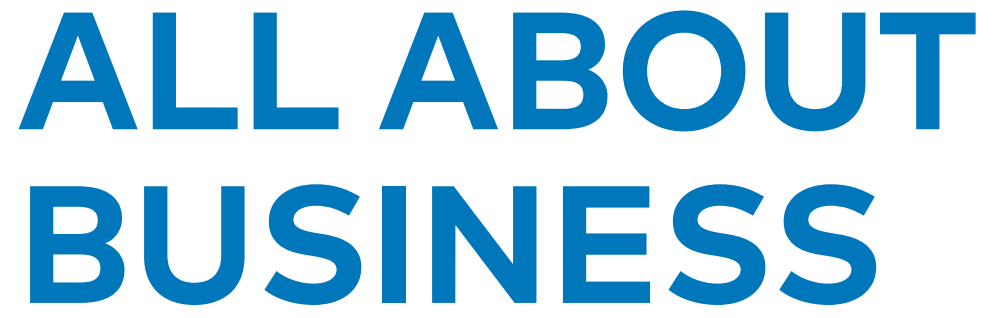

NORDIC WOMEN ON BOARDS AND IN LEADERSHIP

THINK-PIECE

ISELIN LØVSLETT DANBOLT 



\section{CONTENTS}

7 All about business:

Nordic women on boards and in leadership

9 What works for Nordic working women?

12 En route to female leadership in the Nordic countries

17 Boosting Nordic boardroom balance

20 An optical illusion or cracks in the glass ceiling for Nordic women CEOs?

25 Moving the needle towards a Nordic female future in leadership: Challenges and opportunities 


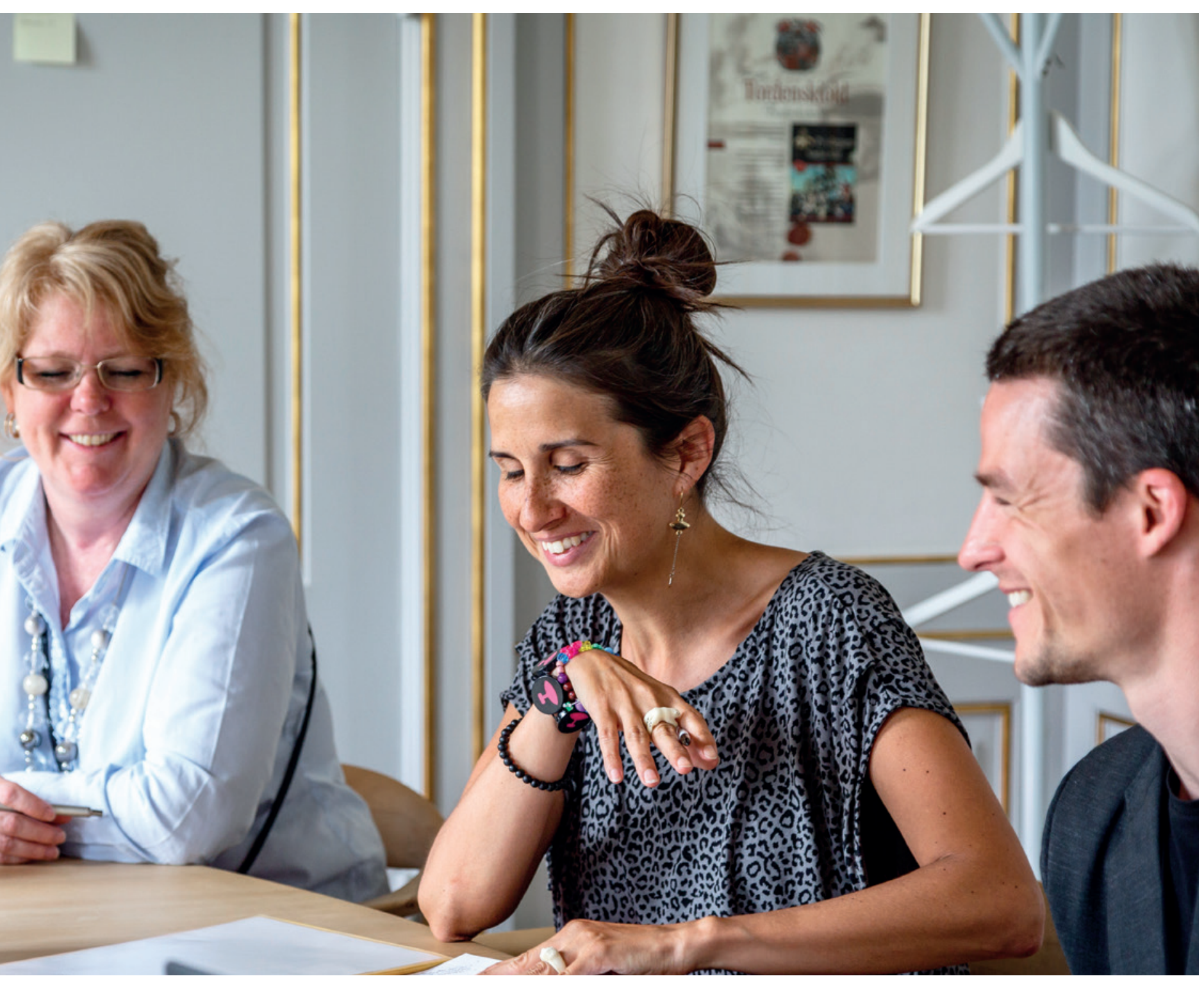




\section{ALL ABOUT BUSINESS: NORDIC WOMEN ON BOARDS AND IN LEADERSHIP}

"Women hold up half the sky", goes the saying. Put in financial terms, this can be impressive indeed. The "power of the purse" is growing faster than ever: women today represent a growth market more than twice the size of China and India, combined. In 2013 it was estimated that women controlled USD 29 trillion in global consumer spending, own or operate between 25-33 per cent of all private businesses, and earned an estimated USD 13 trillion. By 2018, it is projected that working women will experience an increase of about USD 6 trillion in earned income, globally (Catalyst, 2015). For companies that figure out what women want, the future looks rosy indeed. Since 2015, globally the proportion of senior business roles held by women has already gone up from 22 per cent to 24 per cent (Medland, 2016).
Over the past 10 years in particular, the Nordic countries (including Finland, Denmark, Sweden, Iceland, Norway, the Faroe Islands, Åland and Greenland)-often described as the equal opportunity "leaders of the pack" when it comes to gender equality-have put into action legislation, policies, guidelines, mechanisms and initiatives to ensure that women are well represented on company boards and promoted into key leadership positions.

Evidence has shown that gender diversity is not just the right thing to do, but also the smart thing to do by being inherently good for business: not just in terms of profit, but also as an emergent necessity for enterprises to thrive and grow. Gender diversity drives transparency, fairness, and innovation and ensures that companies or organisations bear their social responsibility (Hewlett et al., 2013). 


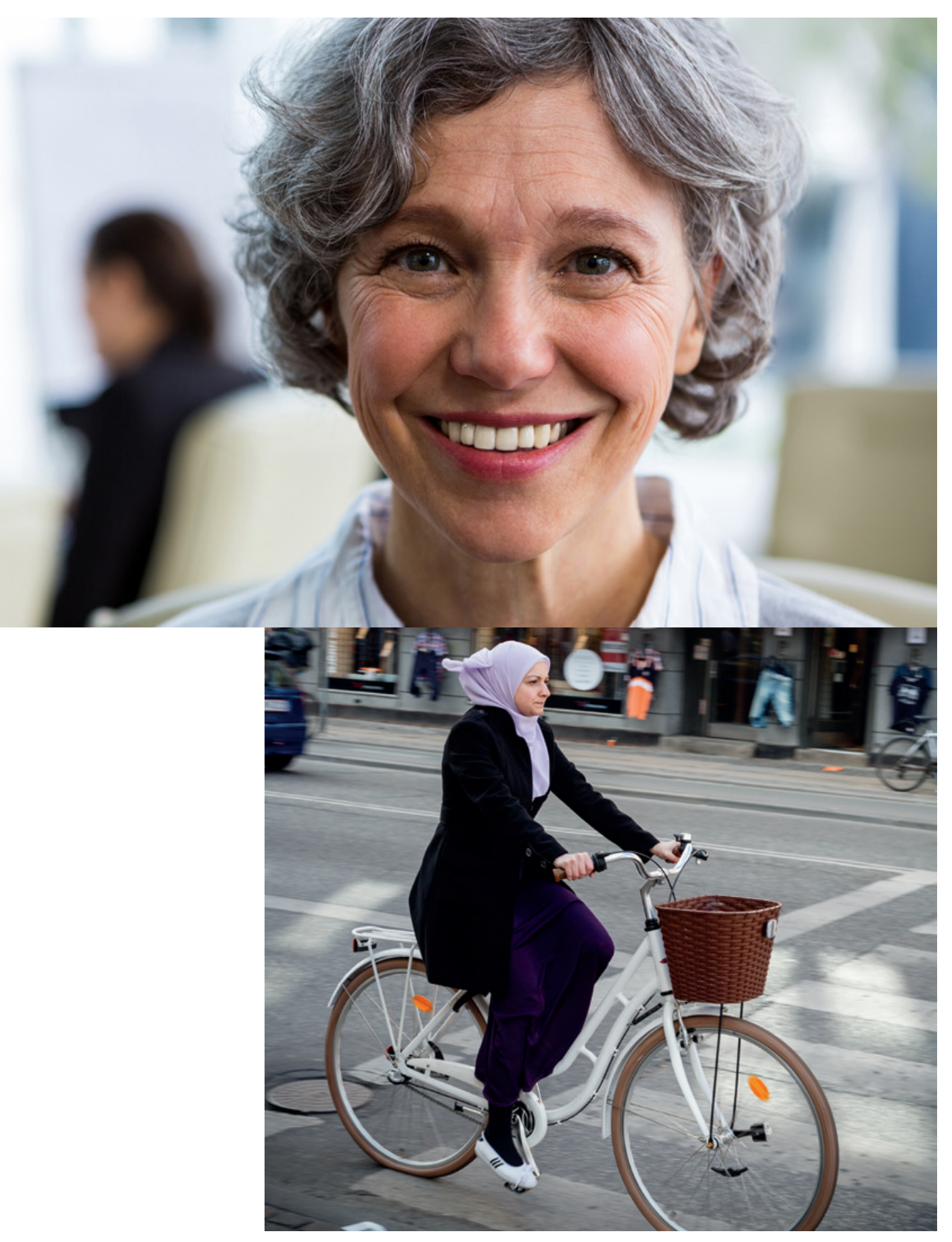




\section{WHAT WORKS FOR NORDIC WORKING WOMEN?}

Today, all Nordic countries find themselves in the top seven of the PwC Women in Work Index-with Iceland, Norway and Sweden maintaining their positions as the top three performers ( $P w C, 2016$ )-and four of the Nordic countries are ranked at the top of the global index of the World Economic Forum's 2015 Global Gender Gap Report (WEF, 2015). Even so, some countries' progress towards gender parity has been uneven.

\section{NORDIC WOMEN MAKING STRIDES IN EDUCATION AND IN THE LABOUR MARKET}

With equality firmly cemented as one of the most important values of Nordic welfare systems and society writ large (EspingAndersen, 1991), one can argue that this has been successfully translated into the region's respective labour market policies, in terms of pay and opportunity (Björk, 2014).

Following two decades of increasing levels of attainment of tertiary education, it was estimated that, in 2014, 61 per cent of those who graduated from higher education institutions in the Nordic countries were women, thus opening up the talent pool for future female leaders (Nordic Statistics, 2016d).

Compared to EU member states' average labour force participation (which reached an all-time high of 64.5 per cent in 2015) (EC, 2016a), women have higher labour force participation rates in the Nordic countries (see table 1). Iceland has the highest proportion of women and men in paid employment in the world, estimated in 2015 to be at 76 and 82.4 per cent, respectively (Statistics Iceland, 2016).

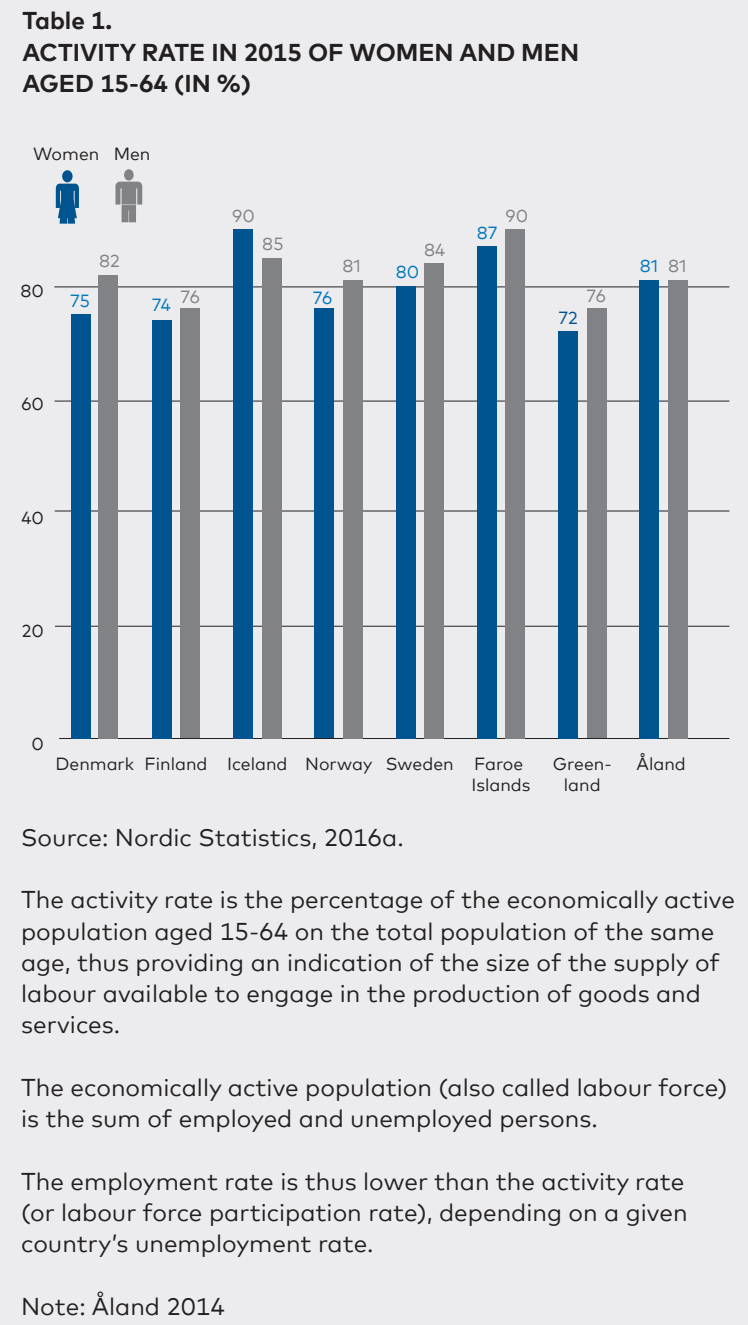

The activity rate is the percentage of the economically active population aged 15-64 on the total population of the same age, thus providing an indication of the size of the supply of labour available to engage in the production of goods and services.

The economically active population (also called labour force) is the sum of employed and unemployed persons.

The employment rate is thus lower than the activity rate (or labour force participation rate), depending on a given country's unemployment rate.

Note: Åland 2014 


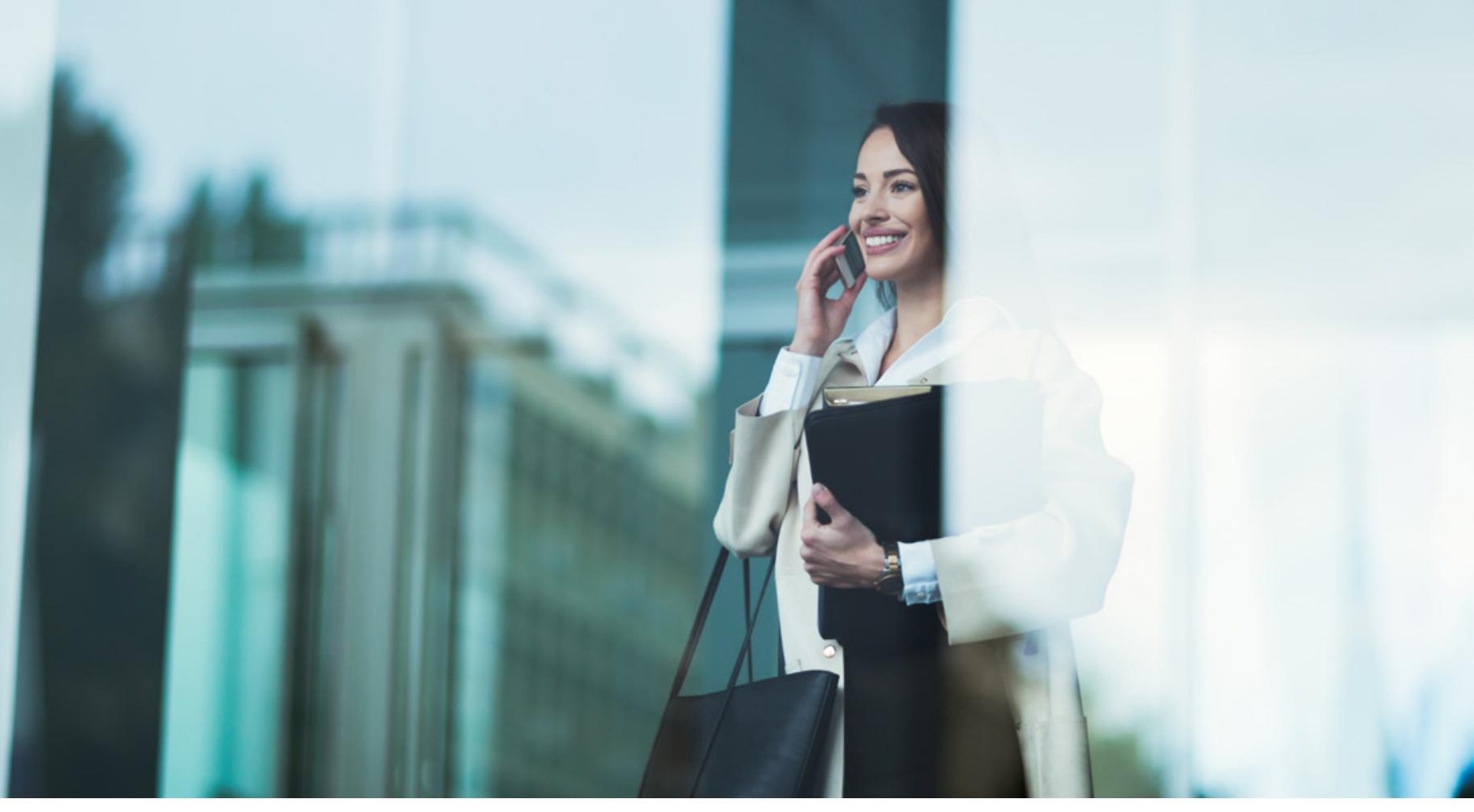

\section{DISPELLING THE NORDIC NIRVANA MYTH FOR WOMEN}

Although more Nordic women are in paid work than elsewhere, the Nordic "nirvana" is far from ideal for all. With labour markets where occupational segregation is common, in 2015, 46 per cent of Nordic women worked in education, health and social services; whereas men were typically concentrated in occupations in the manufacturing, construction, transport, and storage sector (Nordic Statistics, 2016c).

The part-time work rate for women is also higher in most of the region's countries than in most parts of the world. There are, however, striking differences between Denmark, Iceland, Norway and Sweden, on the one hand and Finland, on the other, as Finland has had a longer tradition of female full-time work than their Nordic neighbours (Lanninger and Sundström, 2014). Nordic part-time work (combined voluntary and involuntary parttime) is far more common in the industries where women work-although the share of male part-time workers has increased in all Nordic countries except for Iceland (NCM, 2015).

Whereas working part-time can have a positive impact on work-life balance and general life satisfaction for some, career "penalties" often prevail, such as lower status and pay, fewer training and development opportunities, and lower pensions upon retirement (Lyonette, 2015). Some studies have, however, pointed to a limited forecasted loss in women's pensions in the region as a result of part-time employment, especially in Denmark and Norway (Lanninger and Sundström, 2014).

All over the world women still earn less than men for work of equal value (ILO, 2015), and the Nordic region is no exception. The gender pay gap in Denmark, Norway and Sweden is around 15 to 16 per cent, a little lower than the EU average, which is at 16 per cent. The gap is slightly wider in Finland and Iceland, at around 18-20 per cent. Denmark has the smallest gender pay gap in the Nordic countries (NCM, 2015). 
DID YOU KNOW? All Nordic countries with the exception of Finland are close to-or even exceed-the European 2020 employment target which calls for, at least, a 75 per cent employment rate for both women and men between 20 and 64 years of age (EC, 2010), even when the age group $15-20$ is included. 


\section{EN ROUTE TO FEMALE LEADERSHIP IN THE NORDIC COUNTRIES}

The route to women's leadership and economic empowerment in the Nordic countries certainly passed through ensuring women's right to vote a century agoFinland in 1906, Norway in 1913, Iceland and Denmark in 1915, Sweden in 1919. One could argue that a relatively early acceptance of women's suffrage has played a key role in giving Nordic countries a head start towards gender equality at work, in leadership and in business.

\section{MADE IT, BUT BARELY: NORDIC WOMEN IN POLITICS}

Today, the Nordic countries stand out in terms of female leadership in politics. Norway currently has a female Prime Minister as does the Åland Islands. By 2014, Iceland had had a female president or prime minister for 20 of the past 50 years. Finland and Norway rank close behind, with 12 and 11 years, respectively (Niskanen, 2011). Greenland had a female prime minister in the period 20132014, and Sweden and the Faroe Islands have yet to appoint a female head of government.

In November 2015, women made up 41.1 per cent of parliamentarians, across all chambers, in the region. This figure for Europe as a whole, excluding Nordic countries,
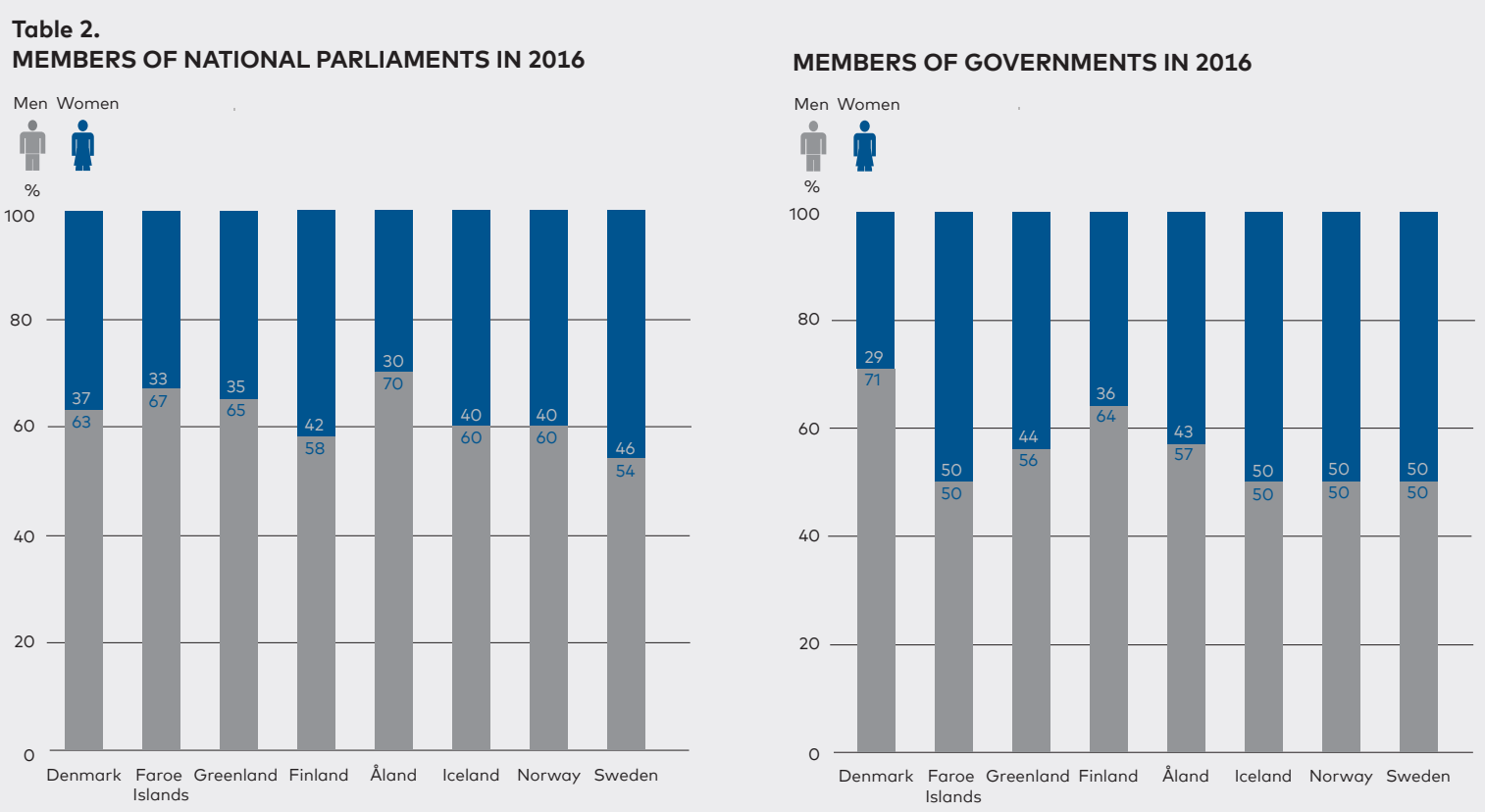

Source: Nordic government and parliament websites. Accessed 20 September 2016. 


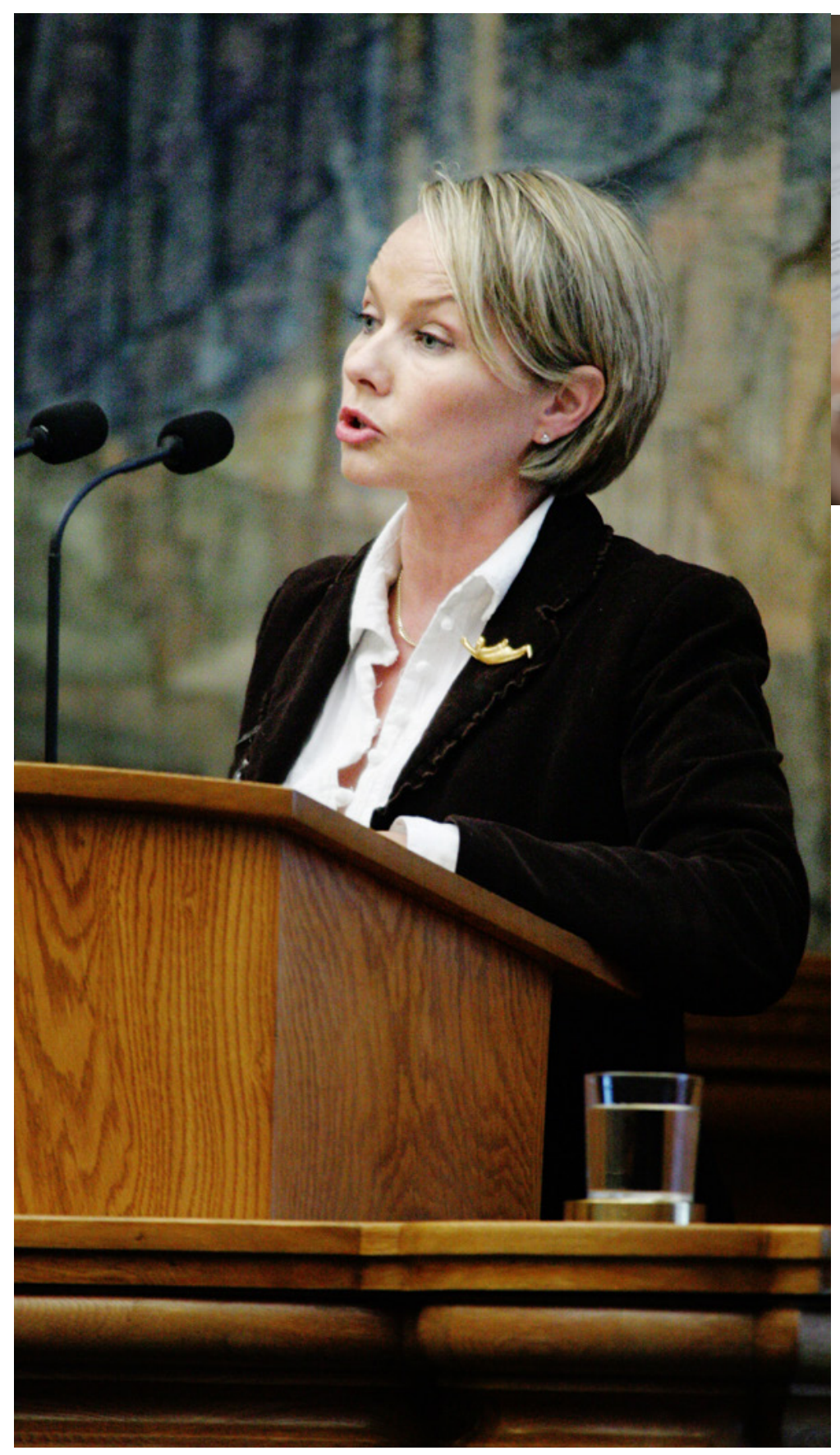


DID YOU KNOW? Denmark introduced a funding programme

in 2014 to improve women's voices in science and technology,

entitled Younger Women Devoted to a UNiversity Career

(DFF-YDUN), and the Nordic Council of Ministers has published

a handbook on how to make STEM subjects more appealing to

girls and young women

(Mørk Puggaard and Bækgaard, 2016).

was 24.4 per cent (UN Women, 2016).

This commendable feat did not happen organically, nor did it happen overnight, as all Nordic countries now have a proportional representation system (NCM, 2015).

Based on the international principle of gender parity being recognised as 40-60 per cent of each sex, the goal of gender balance amongst parliamentarians (see table 2) has been met in 2016 in Finland, Iceland, Norway, and Sweden, with Denmark, Åland, the Faroe Islands and Greenland just below the 40 per cent mark. On average across the region, the goal has also been met with regard to the share of women in ministerial positions, which was at 44 per cent in 2016.

\section{SETTING THE BAR:}

\section{NORDIC WOMEN IN ACADEMIA}

The number of women who complete their tertiary education in the Nordic countries now surpasses that of men and the number of female researchers has been growing at a faster rate than that of men. This has had an effect on the amount of women in academic leadership. In the Nordic region in 2012, women made up between 45 to 52 per cent of all $\mathrm{PhD}$ graduates and figures from 2013 show that 37 to 46 per cent of toplevel academic positions were held by women (EC, 2016b). Many studies have shown, however, that research proposals by men are still more likely to be funded (EC, 2016b). To address this challenge, a range of Nordic countries have put in place programmes aiming to bridge this gap. In 2004, Norway launched its Committee for Gender Balance in Research (KIF), which supports and give recommendations to promote the integration of gender balance and diversity activities at universities, university colleges and research institutes.

Sweden is the only country within the EU28 where female heads of higher education institutions are at 50 per cent (up from 27 per cent in 2010). Iceland, Norway, and Denmark all are above the 30 per cent mark (with 40 per cent, 39.1 per cent and 32.7 per cent, respectively) and Finland has remained at about 25 per cent over the past years. The figures are even more impressive for female heads of universities or institutions accredited to deliver PhDs: in Sweden (50 per cent), Finland (40 per cent) and Norway (38 per cent). The proportion of Nordic women on academic institutions' boards (in the capacity of board members and leaders) gives rise to optimism for women on boards in general, as all Nordic countries reach above the 40 per cent mark, with both Sweden and Finland hing above 50 per cent (EC, 2016b). 


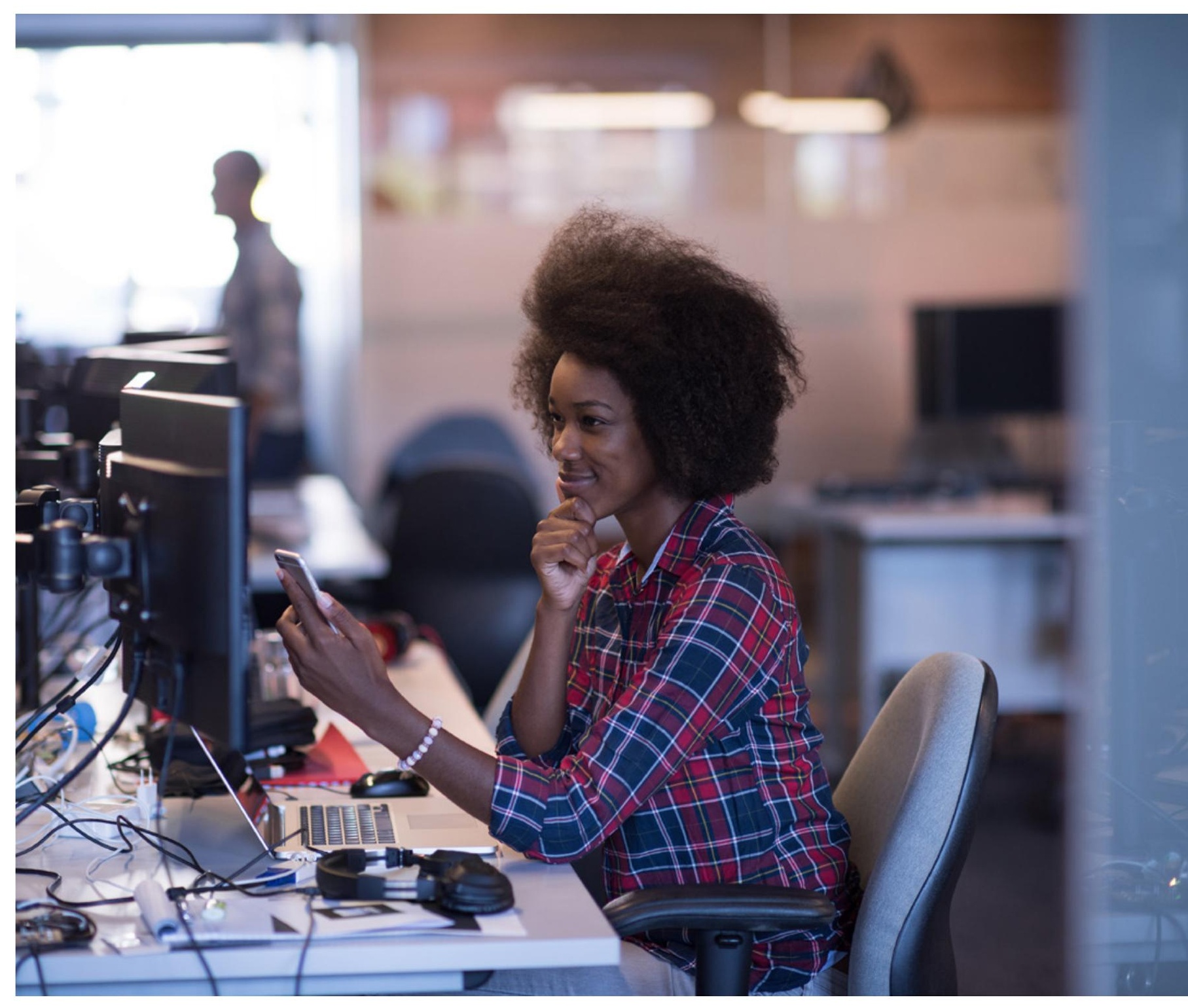


"Corporate boards perform better when they include the best people who come from a range of perspectives and backgrounds."

-Lord Davies of Abersoch, CBE, 2011

Table 3.

SHARE OF FEMALE BOARD MEMBERS ON THE LARGEST PUBLICLY LISTED COMPANIES

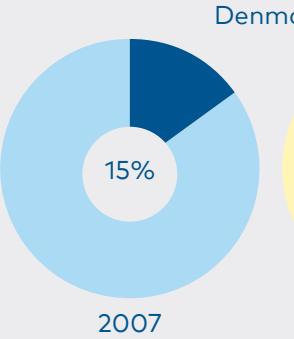

2016

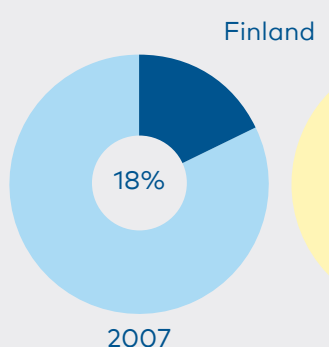

2007

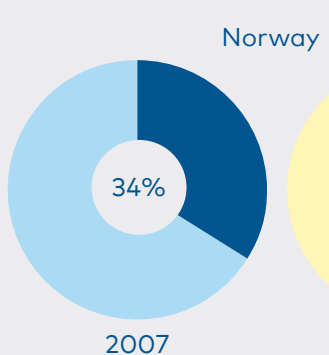

2007

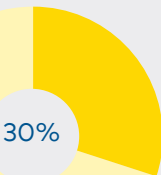

2016

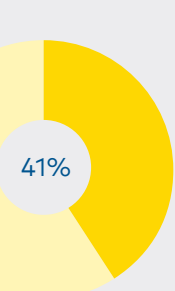

2016

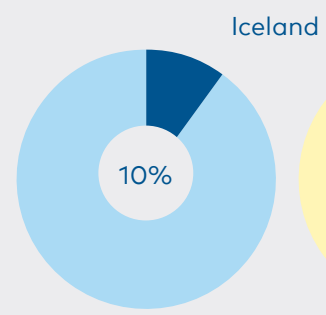

2007

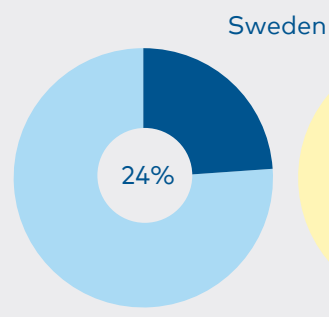

2007
Source: European

Commission, 2016c

The data cover all

members of the highest decision-making body in each company, including chairperson and employee representatives where present.

Publicly listed means that the shares of the company are traded on the stock exchange.

The "largest" companies are taken to be the members of the primary blue-chip index, which is an index maintained by the stock exchange covering the largest companies by market capitalisation and/ or market trades.

The number of companies per country included in the data is between 12 and 26 . 


\section{BOOSTING NORDIC BOARDROOM BALANCE}

From a global perspective the situation of women on boards is dire: only 12 per cent of company boardroom seats are kept warm by women (Deloitte, 2015). Europe is doing slightly better-with the Nordic countries (and others such as France and Italy) taking the lead on diversity on boards. The Nordic region has experienced an accelerated pace of change in board diversity over the past 10 years. Today, it is estimated that 35 per cent of board members on public limited boards in the largest Nordic companies are women (Spencer Stuart, 2015; European Commission, 2016c).

\section{BETTER FOR BUSINESS, BETTER FOR SOCIETY}

Globally, company boards with both women and men are seen to harness the available skills and talent and increase a company's innovation, which also leads to a stronger performance. For instance, a study by Catalyst shows that in the period 2005-2009, the top quartile of Fortune 500 companies with women on their boards overwhelmingly outperformed those in the lowest quartilewith a 16 per cent higher return on sales and a 26 per cent increase in return on invested capital (Catalyst, 2011). For those companies with a continual high representation of women on their boards, these figures grew to 84 per cent and 60 per cent, respectively.

Financial performance, or the "business case", notwithstanding, using skills and talents of both women and men is beneficial for society as a whole (and of course for individual women), as a stronger female presence in the world of work is needed for economic growth and development nationally. Simply put, boards make better decisions when a range of voices that draws on different life experiences are heard. This mix of voices must also include women, as the boardroom is where strategic decisions are taken, good governance put into practice, and risk(s) mitigated.

Over the past 35 years, intense discussions have taken place internationally on why it is important to-and perhaps more importantly how to-get more women onto company boards. All Nordic countries have, at different times, held political debates, considered, and put in place soft regulatory measures or harder legislation on quotas-or both-to strive for gender balanced company boards (Blöndal and Kaltoft Bendixen, 2012). This has led to impressive results across the vast majority of the Nordic region.

\section{NORWAY: A GAME-CHANGING APPROACH}

In 2003 a law was passed requiring at least 40 per cent of either women or men on company boards. As of January 2004 the Quota Act was enforced for state and municipal companies and fully implemented for public limited companies from January 2008, following the amendment of the Norwegian Public Limited Liability Companies Act (Teigen, 2015). With this, Norway became the 


\section{"Stuffy boards with grumpy old CEOs is not \\ a good model." \\ -Svein Rennemo, Chair of Norway's Statoil board}

first country in the world to introduce gender quotas on boards.

Since the Act was put in place, the percentage of women on state-owned, municipal, and public limited company boards has risen from less than 5 per cent in the early 2000s to reach the 40 per cent threshold already in 2007 (Glinski, 2016).

FINLAND: (SELF) REGULATE OR EXPLAIN Gender diversity on boards has been a part of the self-regulatory Finnish Corporate Governance Code for Listed Companies since 2003 (Finland Chamber of Commerce, 2014). Since 2008, the Code includes a recommendation that both women and men are to be represented on boards and that if companies deviate from this they must provide a public explanation and disclose their reasons for non-compliance. Finland's new Corporate Governance Code, which came into force 1 January 2016, stipulates that boards must comprise both women and men, and companies are required to report on their objectives and initiatives to ensure that both women and men are represented on boards (Securities Market Association, 2015). Since 2008, estimates show that the percentage of Finnish listed companies with at least one female board member has increased from 51 per cent to 91 per cent in 2014 (Deloitte, 2015).

\section{SWEDEN: SLOWLY AND SURELY TOWARDS GENDER BALANCE}

In Sweden a number of revisions to the rules of the 2005 Corporate Governance Code came into force on 1 January 2015, also to improve gender diversity of listed company boards. This means that nomination committees should, in their assessment of the board and proposals regarding board composition, give particular consideration to both board breadth and versatility and should strive for gender balance. Furthermore, nomination committees should explain their proposals for striving towards gender balance.

In 2015 the share of women on the boards was at a record high of 28 per cent, compared to about 22 per cent between 2010 and 2013. However, since the proportion of women on listed company boards has not reached 40 per cent, the Government has decided to present a Corporate Gender Quotas Bill to Parliament in spring 2017.

\section{ICELAND: WHEN ONLY QUOTAS WILL DO}

To counter the slow rate of change seen in the private sector, in 2010, amendments to the Laws on public limited companies and private limited companies were passed, including introducing 40 per cent quotas for both women and men on boards, where there are more than three board members (EWL, 2015). 
These amendments make monitoring easier by obliging companies to report on gender diversity status and progress in annual financial statements (WIP, 2014). Since 2013, there has been a huge increase (of 25 percentage points) in the proportion of women on company boards in Iceland which today totals at an impressive 44 per cent-the highest the world over (EWL, 2015).

\section{DENMARK: BUSINESS SETTING THEIR OWN TARGETS}

In 2012, Denmark introduced the Act on Gender Targets and Policies in order to promote women's representation in leadership and executive boardrooms. The Act, which came into force on 1 April 2013, requires Denmark's largest private companies (approximately 1,200 in total) to set targets, design policies and report on their work towards increasing the number of women in top management and executive boards (Hesby Krogh, 2016; Danish Business Authority, 2015b).

Consequently, the share of women on boards in publicly listed companies in Denmark has been steadily increasing in the past five years. Based on a sample from the Danish Business Authority, which includes a relatively high number of publicly listed companies including financial institutions, the number of Danish women, excluding employee representatives, in boardrooms has risen from 7.3 per cent in 2012 to 15.3 per cent in 2016 (Lund Poulsen, 2016; Danish Business Authority, 2015a). In comparison to many of its Nordic neighbours, Denmark has not been an active advocate for gender quotas, but focuses its efforts on ensuring high degrees of corporate flexibility and voluntary action. Denmark remains the only Nordic country, which, by law, requires its largest private companies to design policies on how to reach diversity at the executive management level. 


\section{AN OPTICAL ILLUSION OR CRACKS IN THE GLASS CEILING FOR NORDIC WOMEN CEOs?}

Globally, the proportion of women in senior business roles stands at 24 per cent-two per cent better than what it was in 2015 (Medland, 2016), though only 12 per cent of businesses have a female CEO (Lee, 2014). The ILO found that women are swelling the ranks of lower and middle managers in many regions of the world-in some cases occupying more than half of all jobs. More and more, women are also running their own businesses as entrepreneurs. Around 30 per cent of businesses are now run by women. However, even though there are more women leaders in business, statistically speaking the proportion of women CEOs and board members is still much lower than female participation in the labour market overall and in management in general. This is particularly the case in larger firms. While the glass ceiling may be cracked, it is still far from broken (ILO, 2015b).

The ILO estimates that it could take up to 200 years before there's gender parity at the management level the world over (ILO, 2015b). That is, unless (drastic) action is taken. Numbers aside, a growing body of evidence demonstrates that the abundance of gender diversity quota guidelines, legislation and initiatives-in many ways spearheaded by the Nordic countries-have helped heal the "yawning gender gap" in business. However, there are still not enough Nordic women who have managed to jump all hurdles needed to reach senior management.
As much as Denmark, Iceland, Finland, Norway and Sweden top most global ratings of workplace equality, the region still falls short when it comes to women in the very top positions: in 2016, of the top 102 Nordic companies, 4.8 per cent had female CEOs (EC, 2016d). Also, none of Norway's top 32 companies has a woman in the "C-suite", pointing to a disconnect between boardroom quotas and company hot seats. In 2014, none of Finland's top 27 companies had a female chief either (Zander, 2014). In fact, the countries with the highest proportions of women in senior roles are in the BRICS countries: Brazil, Russia, India, China and South Africa (Saab, 2014).

\section{WAITING (IN VAIN) FOR THE TRICKLE DOWN EFFECT?}

Much like most countries of the world, it appears that the proportion of women in Norway decreases as the elevators go higher up the corporate floors. It was thought that with the introduction of gender board quotas, more female talent would be harnessed and women would, thus, have increased access to more senior management positions. Twenty per cent of women in Norway serve on executive committees (i.e. committees that include the CEO and those reporting to the CEO), with no progress detected since 2014.

Although it is relatively early days to assess the impact of the Icelandic quota legislation on women in management, which came 
DID YOU KNOW? In the wake of the financial and economic crises of 2008 in Iceland-where many argued for a feminist paradigm-female bankers, previously deemed unsuited for management because of the presumption of a "feminine" risk aversion, were subsequently praised for their risk assessments and awareness. In the newly nationalised banks, two out of three bank managers appointed were women and women were subsequently invited to the boardroom whereas the boards of the "boom" were all male

(Thorsdottir, 2014).

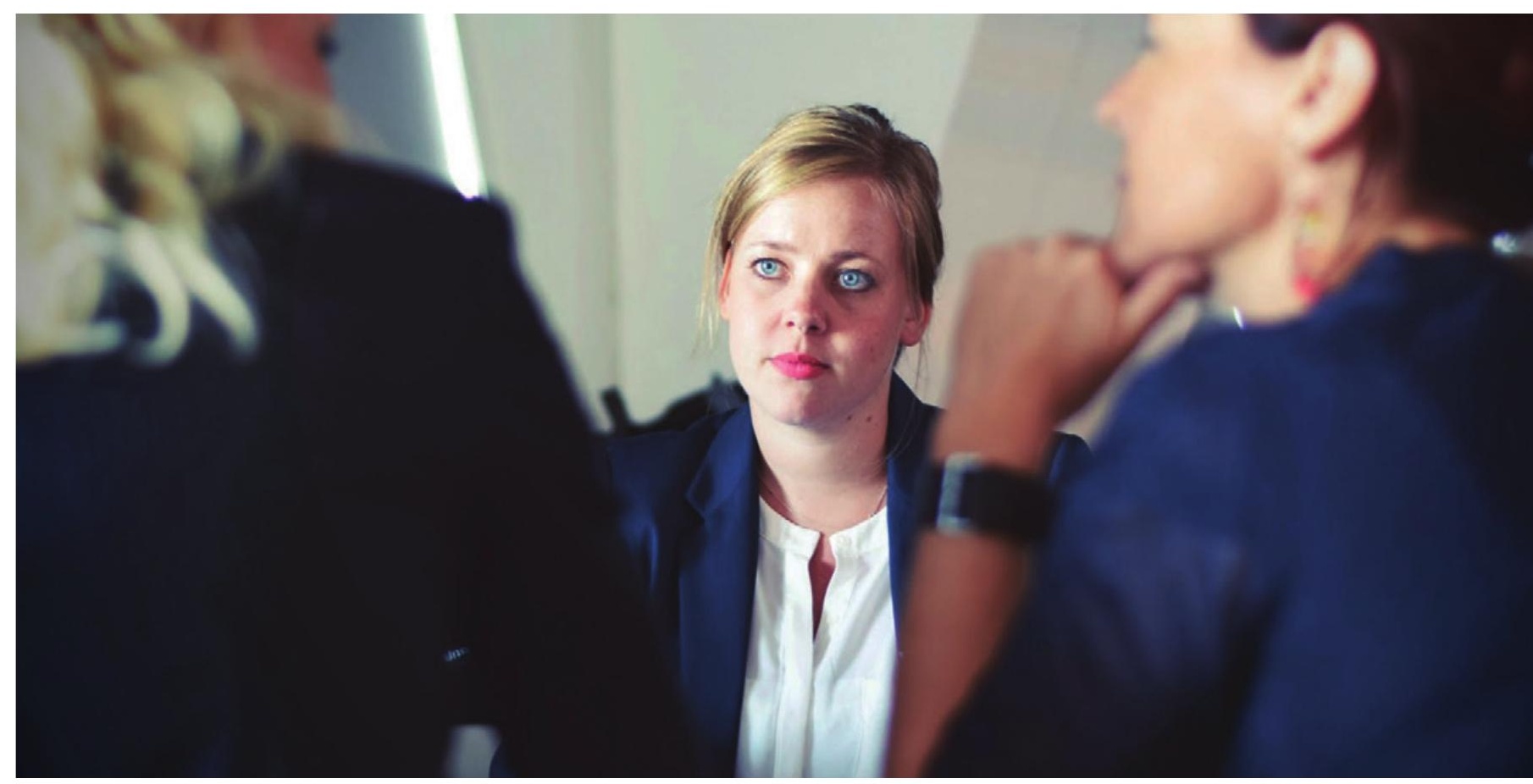

into full force in September 2013, some key conclusions-not entirely unlike the experience of Norway-can be drawn. In Iceland, 17 per cent of executives in the largest Icelandic publicly listed companies are now women, up from 8 per cent in 2012 and 15 per cent in 2014 and 2015. In 2016, 7 per cent of Norwegian and Icelandic CEOs are women (whereas in 2014 and 2013 this figure was 9 per cent and 10 per cent, respectively, showing a slight drop in numbers) and Norwegian female chairs of boards are at 9 per cent in 2016 (CORE, 2016). In Iceland female chairs of boards are at an impressive 40 per cent (up from 0 per cent in 2006) (Nordic Statistics, 2016b). In this regard, Iceland has made impressive progress vis-à-vis its other Nordic neighbours-possibly as a result of the gender quota legislation.

In Norwegian public limited companies, cooperatives and foundations, women occupy 21, 33 and 29 per cent of the board chairs, respectively, but in privately owned private limited companies (PLCs) and limited companies (LTDs), 6-7 per cent of women are sitting at the head of the boardroom table. Women are much less likely to be staff 
DID YOU KNOW? In February 2015 the Finnish

Government set the goal of $\mathbf{4 0}$ per cent gender parity by

1 January 2020 on all boards of directors of large and

medium-sized listed companies.

members of listed companies than public ones (30 per cent and 15 per cent, respectively) (Teigen, 2015), perhaps making the internal female talent pool smaller from which to "fish".

In spite of considerable progress in many areas, a 2015 study on women and men as business leaders in Iceland suggests that executive management is still where the greatest gender discrepancies can be found, while middle management levels are reflecting more gender balance. This study shows that, in executive or senior management, gender parity has been reached in a quarter of companies-whilst 66 per cent still have a majority of male senior or executive managers (Rafnsdóffir et al., 2015).

\section{STEPPING UP FOR PROGRESS?}

In 2014 it was estimated that 20.7 per cent of executives and senior managers in Finnish listed companies (excluding CEOs) were women (Finland Chamber of Commerce, 2014). For the first time ever, four per cent of CEOs are female (up from zero per cent in 2010) and four per cent of board chairs were, in 2015, women. Furthermore, it is estimated that Finnish women comprise almost half of all middle managers (Finland Chamber of Commerce, 2016).

It is estimated that women make up 32 per cent of the boards of the largest companies by market capitalization ("large cap" companies) in Finland today (Finland Chamber of Commerce, 2016). In addition to challenging limited companies through, for instance, revising its Corporate Governance Code, the Finnish Government has, over a considerable period of time and with success, pushed for gender balance in the boardrooms of state-owned companies-which represent a considerable amount of companies in Finland. Some of these measures include numerical targets for achieving gender balanced boards since 2004; the requirement for fully or majority state-owned company boards to have at least 40 per cent women and men; and the promotion of gender equality on the boards of companies where the Government has a minority holding.

In Denmark, evaluations of companies' progress towards gender balance show that 79 per cent have set a target. On average, companies have set targets of a 27 per cent increase in the share of the underrepresented gender (Danish Business Authority, 2015b). Most companies work with a time frame of four years in order to reach the target. The most commonplace company policies refer to human resource measures including recruitment, networking and mentoring (Rolandsen Agustín, 2015).

\section{THE TIDE IS TURNING BUT IS IT FAST ENOUGH?}

As a result of the wide array of measures and legislation put in place to promote 


\section{DID YOU KNOW? In the wake of the financial and economic crises of 2008 in Iceland-where many argued for a feminist paradigm-female bankers, previously deemed unsuited for management because of the presumption of a "feminine" risk aversion, were subsequently praised for their risk assessments and awareness. In the newly nationalised banks, two out of three bank managers appointed were women and women were subsequently invited to the boardroom whereas the boards of the "boom" were all male}

(Thorsdottir, 2014).

more women on boards, Sweden is finally witnessing a rise in women in leadership. For the first time ever, women make up one-fifth of management groups of listed companies. Studies show that a third of companies no longer accept the status quo and are aiming high for greater equality. Gender balanced management teams may even become a reality, sooner than predicted. Should the rate of improvement continue at the same pace as it has over the past four years, all companies will reach at least 40 per cent women in 2040.

The number of women in listed companies' management groups has increased to 20 per cent, an increase of six percentage points since 2012. Companies are thus halfway to reaching gender parity (60/40). Female CEOs are also on the rise: with 16 women currently in companies' "C-suite". The question thus becomes, is the shift towards gender parity moving fast enough to result in more women in leadership?

\section{TIME TO CATCH UP?}

While public limited companies in Faroe Islands, Greenland and Åland are subject to gender equality legislation stipulating a balanced distribution of women and men in public commissions, committees and boards, progress has been slow. The Faroese Act of Equality between Men and Women, which is in accordance with the Danish prototype, does not include provisions for sanctions for authorities or companies that fail to comply. In
2011, the management teams of the fourteen publicly owned companies were entirely male dominated, a little over one-third of board members and little more than 10 per cent of board chairs were women and only men were directors.

In Åland, the Act on Equality between Women and Men, in accordance with the corresponding law in Finland, spells out that there should be an equal representation of women and men on the boards of publicly owned companies, where administrative boards, boards of directors or some other executive bodies consist of elected representatives. In 2011, it was estimated that over one-third of board members and directors in the nine companies that were examined were women. The proportion of board chairs was somewhat lower, a little over 20 per cent (Niskanen, 2011).

In Greenland, the Gender Equality Act stipulates that, as far as possible, publicly appointed boards shall consist of one-half women, one-half men. Before 2011 few companies were able to reach this target. Within a few years, however, all twelve of Greenlandic state-owned companies were in compliance with the Act (Naalakkersuisut, 2015). 
"When you have two per cent of your management pool made by women, there is no way [that] with big principles and good attitudes you are going to [bring about] change this radically. Quotas are important. Why? Because quotas lead to action. Action means hiring, training, coaching, and putting in the process of the company the systematic decision, forcing the selection of female potential at all levels."

- Renault-Nissan Alliance's CEO Carlos Ghosn, World Economic Forum 2014 (Lee, 2014)

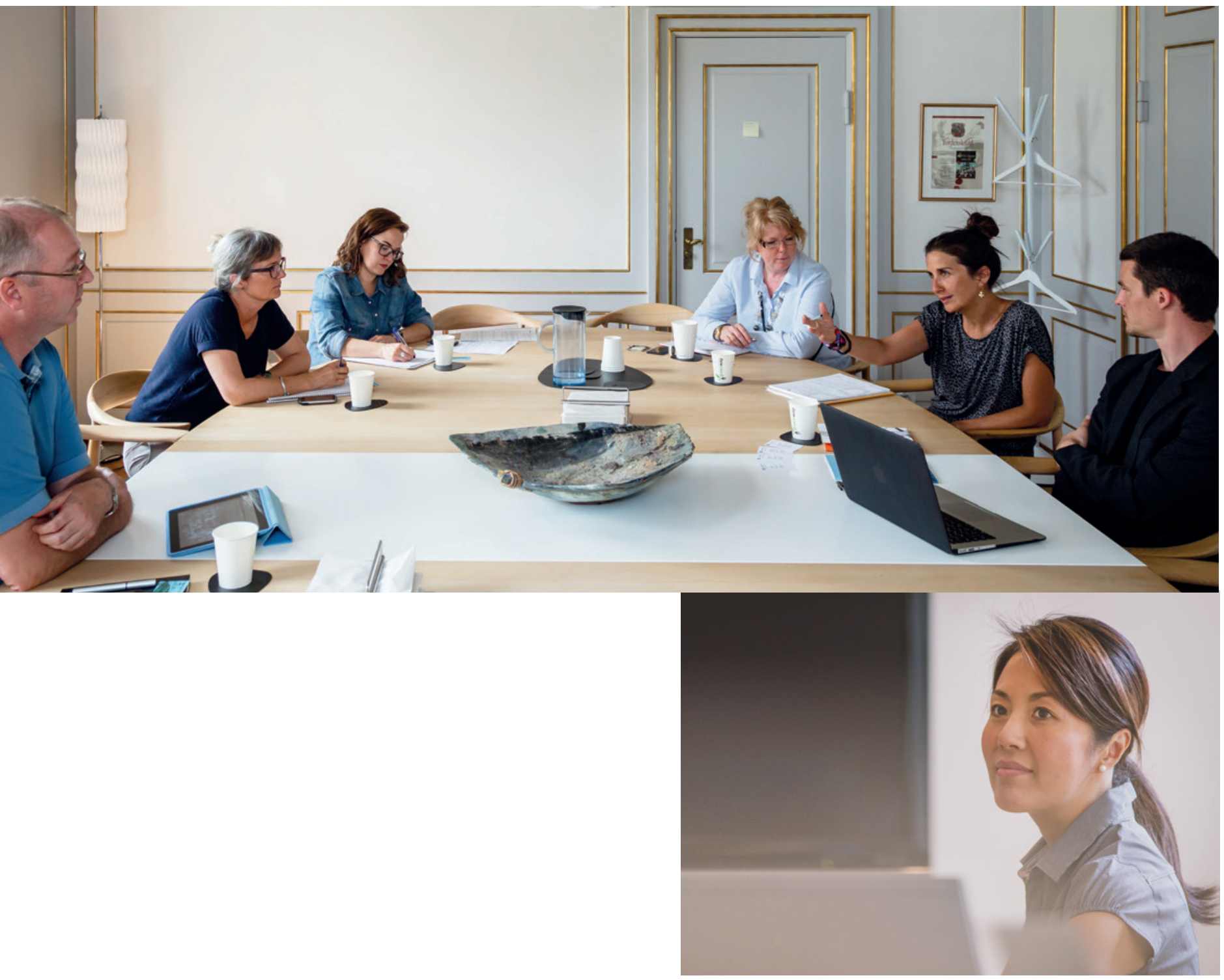




\section{MOVING THE NEEDLE TOWARDS A NORDIC FEMALE FUTURE IN LEADERSHIP: CHALLENGES AND OPPORTUNITIES}

The Nordic countries have worked together on promoting gender equality for more than $\mathbf{4 0}$ years through the Nordic Council of Ministers and in family law for almost a century; they have encountered obstacles and surmounted many of these-individually and collectivelymaking the work ahead on ensuring gender balance in leadership and on boards especially encouraging.

While the region shares similar models for gender equality, the differences between the countries and their approaches cannot and should not be ignored. There is no "one size fits all" approach to getting more women in leadership and board positions. The struggle is far from over and the picture is still fairly bleak for women in leadership within the business world in the Nordic countries, in spite of the range of legislation, policies and other measures put in place to boost women in management. ILO research has pointed to some of the main obstacles holding women back, including gender stereotypes, corporate cultures, difficulties in reconciling work and family responsibilities, as well as more subtle forms of gender biases, which can exist in educational systems and in the workplace (ILO, 2015b).

\section{THE QUESTION OF QUOTAS}

Today, Norway and Iceland have the largest proportion of women in publicly listed company boards in the world-whereas this was far from the case before quota legislation was introduced. And a number of countries (such as Spain, France, and most recently Germany) have followed suit. Sweden's current and self-proclaimed feminist Government has announced a Bill on gender quotas to be discussed in Parliament spring 2017.

Quotas alone, however, may not work, nor would quotas work unconditionally everywhere. Targets will not be reached organically without a change of mind-sets and a range of innovative, tried-and-tested approaches. And also, don't expect a snowball or ripple down effect: Iceland and Norway do not necessarily have more women in other leadership positions, as was the intention. Nor are there, in Norway's case, more women on boards of limited liability companies (LTDs), where owners often have a stronger personal relationship with companies, rather than being accountable to the public (Teigen, 2015). Better gender balance in leadership, at all levels within companies does, however, work (Henriksen, 2016). And many leaders support quotas.

Even German Chancellor Angela Merkel, who originally was against the idea of quotas acknowledges that beyond the immediate and tangible result of more women in the boardroom, quota legislation is "an important step for equality because it will initiate cultural change in the workplace" (Huggler, 2014). 


\section{DID YOU KNOW? A study by Statistics Finland shows that \\ employees were more satisfied with female managers' \\ leadership style than that of male managers}

(Lehto, 2008).

\section{WHEN LESS IS ACTUALLY LESS}

As McKinsey principals argue: a singular legislative framework or programme is not enough. What is needed is an ecosystem of initiatives to propel women into leadership and management (Barsh et al., 2013). Are the current initiatives sufficient? Creating equality in opportunity for both women and men is a complex task that can take time. The problem and solution can often be hidden within women or men, themselves, but also within the companies they work for, and as mentioned above, within the obstacles posed by society at large.

It is largely up to companies, however, to promote women in leadership, and many across the Nordic region have launched various initiatives-with more and more tangible results for women. Some research recommendations call for patience in aiming for results, while others call for heightened focus. With legislation and policy measures that now stem back more than ten years is the region at a point where it can rest on its laurels and wait for the results to be coming in?

Bringing together companies, governments, workers and employers' organisations seems to be the only way to ensure that we begin to see long-term and lasting results (Deloitte, 2015). The ILO, with its tripartite structure and its long-standing commitment to gender equality and women's empowerment, has a number of means to contribute, such as policy recommendations, development cooperation projects and capacity-building on women in business and management.

\section{BETTER RECRUITMENT FOR THE BEST TALENT}

One red thread throughout the different Nordic countries' efforts to ensure gender diversity has been the focus on recruitment and selection processes for top-level jobs. The 2008 economic crisis pointed to the different management styles of women and men. "Had the Lehman Brothers been the Lehman Sisters, the company would not have gone under" is one oft-quoted statement suggesting this. One study posited that characteristics often attributed to women, such as being in possession of soft skills and adopting inclusive approaches may benefit women. Whereas these skills were not viewed as strong management ideals a few decades ago, they are increasingly valued today (Helgesen, 2014). Other studies argue that there seems to be a gap between the views of women and men in senior positions as to how important and effective the recruitment process is for achieving gender diversity on boards and in management positions. It will also help that as the ever growing pool of well educated women gain more relevant experience the more they will gravitate towards these positions in the future, which will increase the talent pool and make it possibly even more difficult for the currently male-dominated corporate universe to deny (Iceland Ministry of Welfare, 2016). 
The case of Iceland confirms the need for more studies on the selection and/or recruitment processes for women on boards to explore linkages between the impact of the quota legislation and unprofessional selection processes for women in leadership (Icelandic Centre for Gender Equality, 2015). In Finland, a real catch-22 was observed, as the key to obtaining leadership positions seemed to be what was on a person's resume. Board members were traditionally been handpicked from those with CEO backgrounds, which few women had. This practice, however, seems to be changing. Today, instead of general managers, board members with specific skill sets are being sought (Koivunen, 2015). In Finland this more inclusive approach to required competences may open up new boardroom opportunities for women and for women in leadership.

Also, in Finland, the practices and composition of recruitment companies and consultants are still widely unknown. Studying, for instance, whether female recruiters are part of placement teams could be an interesting area of further study, for the region and beyond (Koivunen, 2015).

Evidence from Norway indicates that the quota legislation and the formalisation of the selection procedure have brought about a new level of professionalism on recruitment boards in business. This has not necessarily come about solely because of the legislation but also through the development of principles of good corporate governance and management. In turn, this has led to increased transparency in companies (Teigen, 2015) and could be considered good practice for replication. Furthermore, by widening, and not weakening, the talent pool and by searching outside commonly used networks, new and interesting board candidates were discovered-such as younger women specialists in areas highly relevant to the company's strategy, including technology, finance or law. Other candidates were sourced from this search, from diverse backgrounds, and not just women, showing the ripple effects that looking at a larger talent pool can have (Seierstad et al., 2015).

\section{SET THE MANAGEMENT MOMENTUM}

Whereas quotas or other tough measures may be a start, truly progressive companies know that it will take much more to shatter their glass ceilings. Top-level commitment is possibly the first step. Studies have shown that many Danish companies focus on women in leadership from a sense of duty rather than from a place of genuine commitment, especially among top management (Poulsen et al., 2016). It appears that leadership opportunities for women still do not rank high enough on the overall corporate agendas of a range of Nordic countries, and beyond.

A study from Iceland shows that more male than female board members serve on one or more boards, dispelling the "golden skirts" myth of the same women occupying many boardroom seats, in parallel (Rafnsdóttir 


\author{
"There is no equality of chances between women and men; women \\ suffer more obstacles. But only if you address them one by one \\ you will achieve results. Diversity is not part of [corporate social \\ responsibility] but part of the business side, as core of the activity." \\ -Mr Ragon, CEO of DANONE in Belgium
}

et al., 2015). This study also points out that women seem to be a lot more likely to believe that an equal number of men and women in top management will lead to better financial results and improved risk management. Not surprisingly perhaps, women are also significantly more likely to say that gender quotas are an important means of achieving gender equality in the management of companies, in top management and in business as a whole (Rafnsdóttir et al., 2015). Where specific profitability metrics are only considering the short-term bottom line, improvements in organisational culture rarely get placed on top of the agenda. Consistent and genuine support by top management is key-gender diversity needs to be put on the agenda of top managers' key actions and they should recognise their accountability should measures fail. Being a leader is tough, and being a leader of change is even tougher. Management needs to focus on securing both qualifications and diversity, encourage career development and create spaces where opinions can be shared freely. But with strong tools and insights, managers will be equipped to challenge the status quo, and appreciate every voice at work, men and women, alike.

\section{CREATE A WORKING ENVIRONMENT THAT CAN LEAD TO CHANGE}

Putting in place equal pay structures, profamily workplace policies, and putting an end to the undue care burden that often falls on women, are key to retaining women leaders.
Sofia Walk, founder of the Swedish company Wiminvest argues that, instead of offering more money or a car, companies should offer management incentives to women such as private day care, grocery shopping, shared management responsibility or teleworking policies (Saab, 2014). Men, however, also need to be offered similar incentives. Evidence has shown that the most successful gender diversity initiatives include: mentoring and sponsorship schemes-where men also play an active role as mentors and sponsors-as well as training programmes for future female leaders and networking events aiming to boost career growth and confidence (ILO, 2015c).

\section{TIME TO NAME-AND-FAME FOR PUBLIC ENCOURAGEMENT?}

Whereas most Nordic countries have put in place tools and mechanisms to ensure compliance and progress where change has been slow, research often recommends more pressure and harsher measures on those who do not promote women in leadership (Hesby Krogh, 2016). This could also benefit those companies that are promoting gender diversity by offering improved visibility and positive publicity. For instance, in Norway, some companies that did not wish to comply with the quota legislation changed their status from public limited companies to private limited companies. This has resulted in a range of studies as to why they made this decision, potentially serving a source of negative publicity for the companies. The Swedish organisation AllBright publishes yearly "black, 


\section{DID YOU KNOW? A Norwegian study showed that 76 per \\ cent of female senior managers feel that an equitable \\ distribution of work at home is needed for them to \\ succeed}

(Teigen, 2015).

white and grey-lists" of companies evaluating their gender diversity actions. The Danish Business Authority makes yearly reports on companies' efforts to promote women in leadership. Finnish and Icelandic companies are also required to monitor and report on progress.

\section{GET INFORMED ABOUT WHAT WORKS}

The Nordic countries have put in place a range of good practice spaces for women in leadership. For instance, the Danish Benchmark tool (http://ligeledelse.dk/) gives an overview of in-country progress in terms of women in leadership. The Women in Management website (http:// kvinderiledelse.dk/) has been set up in order to share information, guidelines and tools for companies covered by the new laws and to report on progress towards increasing the number of women in top management and executive boards. Similarly, in Iceland, a dedicated website with valuable knowledge and information, has been created by the Centre for Gender Equality on diverse leadership (http://www.fjolbreyttforysta.is), promoted by a widely disseminated video, for all those interested in becoming business leaders or members of company boards. The Gender Equality in Top Management - Changing Practices in Economic Decision Making (TASURI) Project, active from November 2013 to September 2015, aimed to ensure equal gender representation in senior corporate management in Finland and systematically promote women's career development and gender equality at work. One key objective included getting better information on what works for women in the different echelons of management, representing an important first step towards a more regular production of gender-sensitive statistical reports on leadership.

Importantly, several studies have suggested reaching out to women who have successfully climbed the corporate ladder into senior management, so as to obtain first-hand information on obstacles experienced and reflections on how to promote more women into leadership positions. Such guidance will be most compelling, and will also go a long way towards dispelling the myth that there is no point in dreaming if there are no (perceived) opportunities-thereby encouraging women to aspire to management and leadership positions. 


\section{SOURCES}

Barsh, J., Nudelman, S. and Yee, L. (2013). Lessons from the leading edge of gender diversity [article]. McKinsey. Available at: http://www.mckinsey.com/business-functions/organization/ our-insights/lessons-from-the-leading-edge-of-gender-diversity [Accessed 2 July 2016].

Björk, J., (2014). What Scandinavia Can Teach Us About Gender Equality [Blog]. Gap Inc. Available at: http://www.letsdomore. com/blogs/scandinavia-can-teach-us-about-gender-equality/ [Accessed 25 July 2016].

Blöndal, E. and Kaltoft Bendixen, J. (2012). Women on boards and women in management - A comparative over-view of regulation in Iceland and Denmark. Reykjavík: Félagsvísindastofnun Háskóla Íslands.

Catalyst, (2011). The Bottom Line: Corporate Performance And Women's Representation On Boards (2004-2008). New York: Catalyst.

Catalyst, (2015). Buying Power: Global Women. New York: Catalyst.

Centre for Research on Gender Equality (CORE), (2016). Norwegian Gender Balance Scorecard (May 2016) [online]. Available at: http://likestillingsforskning.no/.../CORE_ NorwegianGenderBalanceScorecard_May2016.pdf [Accessed 28 July 2016].

Danish Business Authority, (2015a). Kønsfordeling i de største danske virksomheder [report]. Available at: https:// erhvervsstyrelsen.dk/sites/default/files/media/koensfordeling_i_ de_stoerste_danske_virksomheder_januar_2015.pdf [Accessed 11 October 2016].

Danish Business Authority, (2015b). Den kønsmæssige sammensætning af ledelsen - Opfølgning på reglerne om måltal og politikker [report]. Available at: https://erhvervsstyrelsen.dk/ den-koensmaessige-sammensaetning-af-ledelsen-opfoelgningpaa-reglerne-om-maaltal-og-politikker [Accessed 14 Oct 2016].

Deloitte, (2015). Women in the boardroom: A global perspective, fourth edition [online]. Available at: http://www2.deloitte.com/ women-in-the-boardroom [Accessed 28 July 2016].

Esping-Andersen, G. (1991). The three worlds of welfare capitalism. Princeton: Princeton University Press.

European Commission (EC), (2010). Europe 2020: A strategy for smart, sustainable and inclusive growth. Communication from the Commission: COM(2010)2020 final.

European Commission (EC), (2016a). 2015 Report on equality between women and men in the European Union. Commission Staff Working Document: SWD(2016)54.

European Commission (EC), (2016b). She Figures 2015: Gender in Research and Innovation. Luxembourg: Publications Office of the European Union.

European Commission (EC), (2016c). Board members [online]. Available at: http://ec.europa.eu/justice/gender-equality/genderdecision-making/database/business-finance/supervisory-boardboard-directors/index_en.htm [Accessed 11 October 2016].

European Commission (EC), (2016d). Executives and nonexecutives [online]. Available at: http://ec.europa.eu/justice/ gender-equality/gender-decision-making/database/businessfinance/executives-non-executives/index_en.htm [Accessed 17 October 2016].
European Women's Lobby (EWL), (2015). Women on Boards 2nd Progress Report - Country in Focus Iceland. Cracks in the Glass Ceiling or Just a Trick of the Light? [online]. Available at: http://www.womenlobby.org/Women-on-Boards-2nd-ProgressReport-Country-in-Focus-ICELAND [Accessed 29 July 2016].

Finland Chamber of Commerce, (2014). Women executives stepping up for more business responsibility, Women Executives Report 2014 [online]. Available at: http://naisjohtajat.fi/ files/2016/05/finland-chamber-of-commerce-women-executivesreport-2014.pdf [Accessed 28 July 2016].

Finland Chamber of Commerce, (2016). A record number of women directors in Finnish listed companies [online]. http:// kauppakamari.fi/en/2016/06/10/a-record-number-of-womendirectors-in-finnish-listed-companies/ [Accessed 28 July 2016].

Glinski, N. (2016). Women on Boards [article]. Bloomberg. Available at: https://www.bloomberg.com/quicktake/womenboards [Accessed 29 July 2016].

Helgesen, S. (2014). How Women Leaders Have Transformed Management. Strategy + Business [blog]. Available at: http:// www.strategy-business.com/blog/How-Women-Leaders-HaveTransformed-Management?gko=9e1ad [Accessed 28 July 2016].

Henriksen, M. (2016). Gender diversity - how to get more women into senior management [blog]. Ennova. Available at: http://int.ennova.com/blog/morten-henriksen/genderdiversity-\%E2\%80\%93-how-to-get-more-women-into-seniormanagement.aspx [Accessed 2 July 2016].

Hesby Krogh, A. (ed.) (2016). Kvinder i ledelse. Analyse af lov om måltal og politik for det underrepræsenterede køn. Copenhagen: The Danish Institute for Human Rights.

Hewlett, S.A., Marshall, M. and Sherbin, L. (2013). How women drive innovation and growth. Harvard Business Review [article]. Available at: https://hbr.org/2013/08/how-women-driveinnovation-and [Accessed 25 July 2016].

Huggler, J. (2014). German boardrooms to introduce female quotas [article]. The Telegraph. Available at: http://www. telegraph.co.uk/news/worldnews/europe/germany/11255970/ German-boardrooms-to-introduce-female-quotas.html [Accessed 1July 2016].

Icelandic Centre for Gender Equality, (2015). Board members' selection process post gender quota legislation [online]. Available at: http://www.jafnretti.is/D10/_Files/\%C3\%9Er\%C3\%B6stur_ FFgl\%C3\%A6rur.pdf [Accessed 25 July 2016].

Iceland Ministry of Welfare (2016) Gender diversity on corporate boards and in senior management. Unpublished document from the Ministry of Welfare, Iceland, 2016.

International Labour Organization (ILO), (2015a). Pay equity: A key driver of gender equality [online]. Available at: http://www.ilo. ch/wcmsp5/groups/public/---dgreports/---gender/documents/ briefingnote/wcms_410196.pdf [Accessed 9 October 2016].

International Labour Organization (ILO), (2015b). Women in Business and Management: Gaining Momentum, Global Report. Geneva: International Labour Organization.

International Labour Organization (ILO), (2015c). Women on boards: Building the female talent pipeline [online]. Available at: http://www.ilo.org/gender/Informationresources/Publications/ WCMS_410200/lang--en/index.htm [Accessed 29 June 2016]. Koivunen, T. (2015). Gender equality in the recruitment of senior 
corporate management: Executive Summary. Helsinki: Ministry of Social Affairs and Health.

Lanninger, A.W. and Sundström, M. (2014). Part-Time Work in the Nordic Region: Part-time work, gender and economic distribution in the Nordic countries. Copenhagen: Nordic Council of Ministers.

Lee, A. (2014). Gender Quotas Worked in Norway. Why Not Here? [article]. New Republic. Available at: https://newrepublic. com/article/119343/impact-quotas-corporate-gender-equality\# [Accessed 28 July 2016].

Lehto, A-M. (2008). 'Naiset valtaavat esimiespaikkoja' Hyvinvointikatsaus 3/2009, Tilastokeskus [online]. Available at: http://www.stat.fi/artikkelit/2009/art_2009-09-30_005.html?s=0 [Accessed 19 September 2016].

Lund Poulsen, T. (2016). Besvarelse af spørgsmål 94 alm. del stillet af udvalget den 13. maj 2016 efter ønske af Rasmus Horn Langhoff (S). Ligestillingsudvalget 2015-2016, LIU Alm.del endeligt svar på spørgsmål 94, Erhvervs- og Vækstministeriet [online]. Available at: http://www.ft.dk/samling/20151/almdel/liu/ spm/94/svar/1328617/1639454/index.htm [Accessed 4 October 2016].

Lyonette, C. (2015). Part-time work, work-life balance and gender equality, Journal of Social Welfare and Family Law. Vol. 37, no. 3, pp. 321-333.

Medland, D. (2016). Today's Gender Reality In Statistics, Or Making Leadership Attractive To Women. Forbes. [article]. Available at: http://www.forbes.com/sites/ dinamedland/2016/03/07/todays-gender-reality-in-statisticsor-making-leadership-attractive-to-women/\#2dfc09476255 [Accessed 2 August 2016].

Mørk Puggaard, K. and Bækgaard, L. (2016). Handbook on how to make Science, Technology, Engineering and Mathematics (STEM) more appealing to girls and young women. Copenhagen: Nordic Council of Ministers.

Naalakkersuisut, (2015). Selvstyrets Aktieselskaber - Årlig redegørelse til Inatsisartut 2015 [online]. Available at: http:// naalakkersuisut.gl/da/Naalakkersuisut/Departementer/ Formandens-departement/Bestyrelsessekretariatet/ Redegoerelser [Accessed 4 October 2016].

Niskanen, K. (2011). Gender and Power in the Nordic Countries: A Comparative Perspective. In: Niskanen, K. (ed.) (2011) Gender and Power in the Nordic Countries - with focus on politics and business. NIKK Publications 2011:1. Olso: NIKK.

Nordic Council of Ministers (NCM), (2015). Nordic Gender Equality in Figures 2015. Copenhagen: Nordic Council of Ministers.

Nordic Statistics, (2016a). WORK02: Employment and unemployment by reporting country, employment status, sex and age. Available at: http://norden.statbank.dk/ [Accessed 12 October 2016].

Nordic Statistics, (2016b). LABO08: Board members of larger publicly listed companies by reporting country, type of position and sex. Available at: http://norden.statbank.dk/ [Accessed 28 July 2016].

Nordic Statistics, (2016c). LABO06: Employed aged 15-64 1 January by reporting country, industries, unit and sex. Available at: http://norden.statbank.dk/ [Accessed 11 October 2016].
Nordic Statistics, (2016d). EDUC03: Number of students graduated by reporting country, age, level, field of education and sex. Available at: http://norden.statbank.dk/

[Accessed 11 October 2016].

Poulsen, M-B., Brackert, T., Skov, S-M. and Nielsen, L.H. (2016). Creating Value with Gender Diversity in Danish Companies. Boston Consulting Group.

PwC, (2016). Women In Work Index 2016 [online]. Available at: http://www.pwc.co.uk/services/economics-policy/insights/ women-in-work-index-2016.html [Accessed 25 July 2016].

Rafnsdóttir, G.L., Axelsdóttir, L., iðriksdóttir, S. and Einars, D. (2015). Women and men as business leaders in Iceland. Reykjavik: University of Iceland.

Rolandsen Agustín, L. (2015). The Policy on Gender Equality in Denmark - Update. Brussels: European Parliament.

Saab, M. (2014). The Surprising Countries With More Women in Corporate Leadership Than the U.S.-Or Even Scandinavia [article]. Time. Available at: http://time.com/2861431/femaleexecutives-gender-quotas/ [Accessed 2 August 2016].

Securities Market Association, (2015). Finnish Corporate Governance Code 2015. Available at: http://cgfinland.fi/ files/2015/10/hallinnointikoodi-2015eng.pdf [Accessed 8 October 2016].

Seierstad, C., Huse, M. and Seres, S. (2015). Lessons from Norway in getting women onto corporate boards [article]. Available at: http://theconversation.com/lessons-from-norway-in-gettingwomen-onto-corporate-boards-38338 [Accessed 25 July 2016].

Spencer Stuart, (2015). 2015 Nordic Board Index [online]. Available at: https://www.spencerstuart.com/research-andinsight/2015-nordic-board-index [Accessed 28 July 2016].

Statistics Iceland, (2016). Employed - number and percent by quarters 2003-2016. Available at: http://www.statice.is/ [Accessed 9 October 2016]

Teigen, M. (ed.) (2015). Gender balance on company boards: A summary from a research project about the impact of the Norwegian gender quota legislation. Report 2015:02, Institute for Social Research.

Thorsdottir, T.K. (2014). Iceland: From feminist governance to gender-blind austerity? Gender, Sexuality and Feminism. Vol. 1, no. 2 , pp. 24-41.

UN Women, (2016). Facts and Figures: Leadership and Political Participation. Women in parliaments [online]. Available at: http:// www.unwomen.org/en/what-we-do/leadership-and-politicalparticipation/facts-and-figures [Accessed 5 August 2016].

Women in Parliaments Global Forum (WIP), (2014). Why is Iceland the world's global leader in gender equality? [online]. Available at: http://www.womeninparliaments.org/why-isiceland-the-world-s-global-leader-in-gender-equality/ [Accessed 29 July 2016].

World Economic Forum (WEF), (2015). Global Gender Gap Report 2015. Geneva: World Economic Forum.

Zander, C. (2014). Even Scandinavia Has a CEO Gender Gap [article]. The Wall Street Journal. Available at: http://www.wsj.com/articles/SB100014240527023039800045795 76074106113980 [Accessed 28 July 2016]. 


\section{(11) Nordic Council of Ministers}

Ved Stranden 18

DK-1061 Copenhagen $\mathrm{K}$

www.norgen.org

Nordic approaches to ensure gender equality in the labour market are garnering more and more interest the world over. This thinkpiece reviews and discusses Nordic solutions for boosting gender balance in leadership. While it is no longer possible to ignore the benefits of gender diversity in business and politics, the Nordic countries have used different approaches to get more women than ever into leadership positions and company boards, such as gender parity quotas and corporate governance codes. However, there is more work to be done, as prevailing mind-sets and practices are still barriers for women to crack the glass ceiling.

The think-piece raises key points for discussion on gender equality in the Nordic region, giving input into ongoing Nordic cooperation and the International Labour Organization's Women at Work Centenary Initiative. 